\title{
Evaluation of flatulence of uterus (Nafkhat-ol-rahem) as one of the causes of infertility in women from the viewpoint of Ali ibn Abbas Ahvazi and modern medicine
}

\author{
Zeinab Zaheri', Mojgan Tansaz², Fereshteh Golfakhabadi*
}

\author{
'Medicinal Plant Research center, Department of Pharmacognosy, school of Pharmacy, Ahvaz Jundishapur University of Medical Sciences, Ahvaz, Iran \\ ${ }^{2} 5$ chool of Traditional Iranian Medicine, Shahid Beheshti University of Medical Sciences, Tehran, Iran \\ *Correspondence to: Fereshteh Golfakhabadi (golfakhrabadi@yahoo.com) \\ (Submitted: 03 March 2020 - Revised version received: 23 March 2020 - Accepted: 11 April 2020 - Published online: 26 June 2020)
}

\begin{abstract}
Objective Today, infertility and its complications are one of the largest problems because it would impose economic burden and psychological pressure on the people. One of the infertility reasons in most Iranian traditional medicine (ITM) manuscripts are focused on Nafkhat-ol-rahem.

Methods In this study, the Ibn Abbas theories in kamel al-Sina'ah about Nafkhat-ol-rahem, causes, reasons, and treatment were investigated. To achieve recent studies, searches were performed in the databases with the keywords including vaginal flatus, vaginal flatulence, and pelvic floor weakness.

Results This disease is caused by bad cold temper, hit, and obstruction of cervix, etc. Traditional medicine considered the bloating of uterus (Nafkhat-ol-rahem), the cause of some miscarriages and infertility, because dense gas that accumulated in the uterus, prevents implantation and establishment of the embryo. In ITM, treatment involves the use of warm and mohallel riyah (gas dissolvent) herbal medicines in the form of oral, poultice (topical ointment), Forzajeh and Homol (vaginal suppository).

Conclusion Nafkhat-ol-Rahem is a highly prevalent disease in women, but because of the shame, the patient does not speak with her doctor. Bloating of uterus and vaginal flatulence are seen in the pelvic floor muscle relaxation, which can be harmless or associated with major complications such as rectovaginal fistula and infection of the uterus.

Keywords Nafkhat-ol-rahem, Infertility, Ali ibn Abbas, Iranian traditional medicine
\end{abstract}

\section{Introduction}

Concerning the history of human life, for a long time, "infertility" has been a topic of interest for scientists that lead to the discovery of the causes of this disease. However, $15-25 \%$ of infertility cases are still called idiopathic. ${ }^{1}$

WHO describes infertility as below:

Infertility is a genital disorder and includes failure to get pregnant after 12 months or more of regular and unprotected sexual intercourse (without any other causes such as breastfeeding or postpartum amenorrhea). Primary infertility including infertility in couples who have any children, secondary infertility is an inability to get pregnant again.

Infertility has a high prevalence and occurs in $10-15 \%$ of couples. In $45 \%$ of cases, infertility is related to female disorders such as ovarian diseases (polycystic ovary), disorders of fallopian tubes, uterine abnormalities (endometriosis). $30 \%$ of infertility is related to men and $25 \%$ of cases, have no clear cause. $^{1}$

In all Iranian traditional manuscripts, infertility and uterine diseases have been investigated and their causes and symptoms described in detail and categorized. In Iranian traditional medicine (ITM), sterility and infertility are called "Oghr" and "osr ol-habal" which means "infertility" and "difficult to getting pregnant". $2-4$

The use of complementary medicine in the treatment of infertility is increasing. Acupuncture, homeopathy, herbal remedies, massage therapy, etc. are the methods that are now promoted by their proponents..$^{5-7}$

In traditional medicine, various reasons have been expressed for infertility in women, including disorders in female semen, diseases that occur in the uterus such as types of uterine abnormalities, uterine hemorrhoids, cervical inclination, and flatulence in uterine and severe swelling in cervix. ${ }^{2,4,8}$

One of the reasons for infertility that is mentioned in traditional manuscripts is uterus flatulence. In this study, the etiology and treatment of this disease have been investigated from the perspective of Hakim Ali Ibn Abbas Ahvazi in the Kamel Al-Sina’ah al-Tebiyah.

\section{Method}

This is a review article in which one of the authentic books in ITM called kamel al-Sina'ah al-Tebiyah, written by Hakim Ali ibn Abbas Ahvazi, was investigated. Related content to Nafkhat-ol-rahem disease, causes and symptoms were collected and the role of this disease in infertility was investigated. The treatment method and the measures needed to improve the disease were studied. Some of the compounds that are used to treat this disease were collected along with their profiles. Also, some of the compound medications used in the treatment of this disease in the kamel al-Sina'ah were also collected in separate tables.

To investigate and compare this disease in current medicine, the PubMed, science direct, and Google scholar databases were searched using the keywords vaginal flatus, vaginal flatulence, and pelvic floor weakness. Based on the results, the cause of uterine bloating and vaginal flatus was investigated and some of its causes were identified. Also, treatment methods of this disorder in current medicine was adapted to the treatment and remedies described in ITM. 


\section{Results}

Special attention has been paid to infertility in ITM, so part of the great manuscripts of ITM dedicated to the causes and treatment of infertility. Infertility is called Oghr in traditional medicine, ${ }^{2,4,8-11}$

\section{The Structure of the Uterus from the Perspective of Ali ibn Abbas}

Ali ibn Abbas Ahvazi has been described as the structure of the uterus. The uterus is similar to bladder in the shape and has two branches on both sides, where the semen is entering in. During pregnancy and development of the fetus, the uterus can be enlarged and drawn in all directions without getting damage. The uterus is composed of a layer, and this layer consists of a series of woven warps that are in various directions (longitudinal, diagonal, and transvers). Uterine has two spaces on the right and left side of the ends to a single depth that is named cervix (neck of the uterus). The uterus is located on the rectum and under the bladder, and thus is protected; it is also connected by ligaments to the surrounding limbs, so it can be drawn in all directions during pregnancy. ${ }^{12}$

\section{Causes of Infertility from the Perspective of Ali ibn Abbas}

Iranian Medicine, is a humoral system. According to the principles of ITM, the human body consists of four humors: dam (blood), balgham (phlegm), safra (yellow bile), and soda (melancholy). These humors have specific qualitative and quantitative characteristics. The imbalance in temperament (Mizaj) and humors (Akhlat) is the cause of disease, therefore treatment is based on restoring and maintaining this balance. Infertility in a couple is due to the presence of diseases in men and women. Infertility in women has several causes that ibn Abbas categorized them in two groups: diseases related to su'mizaj and structural disorders. ${ }^{11,12}$

\section{Su'mizaj}

Su'mizaj occurs when an organ's temperament goes out of range. Diseases related to su'mizaj are in two categories: simple su'mizaj and material su'mizaj. ${ }^{9,11,12}$

Simple su'mizaj occurs when one of the four qualities (warmth, coldness, dryness, or wet) overcome an organ. Material su'mizaj is caused by humor overcoming and caused corruption in the organ and altering the quality of that organ. ${ }^{9}$

\section{Diseases Due to Uterus Structure}

The most common cause of infertility is related to the uterus. Pregnancy is only caused if the uterus is healthy and any cause that disrupts its structure can lead to fertility disorder.

Some of these structural disruptions include:

- Cervical obstruction due to factors such as severe swelling, excess tissue, and coldness.

- Retroverted uterus, or coming down and ejection

- Uterus wounds and hemorrhage that causes bleeding.

- Blockage in the blood vessels and seminal tubs in the uterus, which prevents semen from reaching the uterus.

- Uterus swellings

- Bloating in the uterus and wind accumulation in it that causing swelling under the umbilical region. ${ }^{11,13}$

\section{Effect of Uterus Flatulence on Infertility}

The cold su'mizaj of the uterus causes contraction of the vascular and, along with a thick wind (Rih) that penetrates the tissue of the uterus, in the early stages of pregnancy, prevents the implantation of the fetus in the uterus. The probability of abortion in the first 3 months of pregnancy was higher. In traditional medicine, one of the causes of abortion is uterus flatulence, ${ }^{14}$ because the thick winds (Riyah) in the uterus can separate the embryo sheath (amniotic sac) and the Naghr in the uterus (the vascular openings that the blood flows from them into the uterus), which the choroid is attached to, and causes abortion. ${ }^{15}$

\section{Uterus Flatulence from the Perspective of Ali ibn Abbas}

Ibn Abbas in kamel al- Sina'ah al-Tebiyah says "Nafkhat-olRahem is accumulation of thick winds (riyah) in the uterus space for various reasons". ${ }^{11}$ Some causes of uterine flatulence include:

- Cold su'mizaj is the main cause of nafkhat-ol-rahem. Cold su'mizaj causes weakness and suppress the uterus instinctive heat and produce riyah and bloating in it. This riyah can accumulate in the uterus, or penetrate into the depths of the uterus and its tissue. ${ }^{11}$

- Abortion and hard delivery (osr al-veladat) can cause pain and weakness in the uterus, and as a result, the instinct heat of the uterus reduced. ${ }^{1}$

- Cervical closure due to the presence of blood clots in the cervix which prevents the outflow of riyah in the uterus. ${ }^{11}$

If the riyah and bloating are in the uterus, it is easier to treat, but the riyah that penetrates into the depth of the uterus, is not easily treatable. If the patient does not follow all the instructions, she may endure with the disease forever. ${ }^{11}$ Signs and symptoms of this disease include: ${ }^{2,9,11}$

- Bloating, pain and stretch in the pubis and under the umbilical region.

- Due to the presence of bloating, when hit underneath the navel, its sound like a drum.

- Rigidity (stiffness) and abdominal sturdiness.

- Swelling of the pubis area

- Stretching the pain up to the thigh and thigh lymph nodes. Due to the accumulation of lymph material in this area, pain is spread to the legs.

- The stretching of the pain to the stomach and the diaphragm, due to the involvement and attachment of the ligaments of the uterus to the proximity of the stomach and the diaphragm.

- Pain can be relocated from place to place and from the womb to other organs.

- Disposal of gas from the uterus during intercourse.

- Eating flatulent foods will make the patient get worse.

\section{Uterus Flatulence in Recent Medicine}

In the review of the articles, there was no case in which uterine flatulence and its complications were considered as a disease. The uterine bloating is described as an outflow of air or odorless gas from the vagina during walking, physical activity, intercourse, or vaginal examination. Normally, this is a natural phenomenon that occurs when the air enters the vagina and 
then driven out by the normal contraction of the uterus and abdomen muscles. Although this phenomenon is usually safe, it is very uncomfortable for many women and makes them feel embarrassed..$^{16,17}$

Studies have shown that, gas comes out of the vagina is considered as one of the symptoms of pelvic floor muscle dysfunction (PFMD). PFMD is a disorder that causes many social problems and affects family and social life, but its prevalence is not clear. Many women do not report their own problems because they either feel shame about it or they see it as a natural consequence of pregnancy and childbirth or because of their age. For this reason, they prefer to limit their social connections so that they are less likely to be distressed. Common problems with PFMD include prolapse of the pelvic organs (cystourethrocele, rectocele, uterine or vagina prolapse), and urinary incontinence. Vaginal flatulence (Vaginal wind) is another symptom of this disorder. ${ }^{17,18}$

Many women do not know about pelvic floor muscles and their function, and they are unaware of the problems that can be caused by inappropriate functioning of these muscles in their bodies after pregnancy and childbirth. Most women do not have enough knowledge about the association between reduced pelvic floor muscle function with vaginal gas outflow, constipation, and sexual dysfunction. ${ }^{19}$

Normally, the air comes out of the vagina is odorless, but if it has odor, it is a serious disorder. The disorders associated with this gas include the presence of rectal and vaginal fistulas, vaginal surgery, and internal injuries. In the event of any of these, treatment should be taken as soon as possible, otherwise it may cause a uterine infection. Rectovaginal fistula (RF) sometimes occurs after rectal surgery, in which there is disposal of vaginal gas, fecal leakage, and vaginal discharge, which is very annoying. Treatment of these conditions is possible with surgery. In all of these cases, the gas outflow of vagina is not an independent disease, but one of the symptoms associated with these conditions. RF or uterine and vagina prolapse have specific causes and treatment of these disorders is usually done by surgery. In all of these cases, vaginal gas disposal is not an independent disease, but is one of the symptoms associated with these diseases. RF or uterine and vagina prolapse have specific causes, and treatment of these disorders is usually done by surgery. ${ }^{20,21}$

\section{Treatment}

The ITM is based on maintaining health and preventing illness. Each person should know his temperament and adjust his lifestyle accordingly. In order to maintain health, it is essential to observe The Six Principles of Health Preservation (proper nutrition and adequate drinking of healthy water, healthy air, proper sleep, adequate exercise, mental conditions control, preserving essentials, and eliminating useless substances from the body). When disease occurs, therapeutic approaches are required to restore the body to its original temperament and cure the disease. ${ }^{2}$

In the case of uterus flatulence, the treatment is:

- Correcting the nutrition: The patient should avoid eating flatulent and cold temperament foods. Considering that one of the causes of uterine flatulence is cold su'mizaj of uterine, eating foods with hot temperament that produce delicate humors, can prevent uterine bloating and somewhat modulate the cold su'mizaj of the uterus. ${ }^{4}$
- Suitable sleep: Sleeping helps maintain the strength of the various organs and returns health to the body. At the time of sleep, blood goes to the internal organs of the body, which improves their actions and eliminates wastes from them..$^{22}$

- Sufficient exercise: One of the major tools used by the body in treatment is Thermal Therapy that, by increasing body temperature, mildly breaks down and excretes the substance. In the Canon of medicine, Ibn Sina has said that nature, by instinctive heat, repels toxins. In the event of cold su'mizaj, the instinctive heat of the limb is decreased, such as that caused by the uterus flatulence, exercise and mobility creates heat that breaks down the riyah of the uterus. ${ }^{9,22}$

- Drug therapy: Given that cold su'mizaj is the main cause of this disease, herbal medicine with hot temperament that reduce riyah are considered as the first line of treatment. ${ }^{4}$ The drugs listed in the kamel al- Sina'ah are prescribed in several ways:

(A) Oral medicines, such as jovaresh (an oral dosage form) and beverages. ${ }^{12}$

(B) Topical medications

- Oils and poultices - liquid or semi-solid dosage form that can be rubbed on the skin..$^{23}$

- Hoghneh (vaginal enema) - boil some herbs in water, filter the liquid and use it vaginally. ${ }^{23}$

- Forzajeh (vaginal suppository) - a piece of wet wool fabric with dry or wet medicines that used vaginally. ${ }^{23}$

- Humol (vaginal suppository) - a piece of cotton cloth containing a drug that is used vaginally. ${ }^{23}$

(C) Performing manual actions such as using a hot cupping under the umbilicus.

Most of the medicines used to treat this disease have hot and dry temperament, which can be useful in mizaj modulating and eliminating the cold su'mizaj in the uterus. Also, these medications have functions such as dissolvent of thickened winds (mohalel), cleansing (monaghi), cleaner (jaly), cocative (monzej), phlegm repellent, etc., which are used together in the treatment of uterus flatulence. ${ }^{24}$ Specifications and properties of some of the materials (mofradat) that are used in preparation of combinational medicines in kamel Al-Sina'ah (such as the scientific name, traditional and general name, temperament, functions, and properties of these drugs) have been collected from the Makhzan Al-adviyeh book and presented in Table 1.

Several formulas of combinational medicines from the kamel al-Sina'ah book in the treatment of uterus flatulence are listed in Tables 2-5.

\section{Treatment in Modern Medicine}

Motion and exercise cause warmth and heat in the body, which helps breaking down the moisture in the uterus. With less humidity, fewer winds are produced in the uterus, which helps reduce the uterus flatulence. ${ }^{22}$ In modern medicine, to increase the function of the pelvic floor muscle and reduce its complications, these muscles should be tonicated by exercising and moving. One of these exercises is Kegel movements. This exercise should be done regularly and always. The method of doing sports is that the person is sitting or lying on the ground. The pelvic floor muscle then contracts for $5 \mathrm{~s}$, and then relaxes 
Table 1. Specifications of some of medicinal herbs (mofradat) that used in preparation of medicines for the treatment of uterus

flatulence from the kamel al-Sina'ah book of Ibn Abbas's and their properties in the makhzan Al-adviyeh book. ${ }^{11,24}$

\begin{tabular}{|c|c|c|c|c|c|}
\hline & Scientific name & Traditional name & $\begin{array}{l}\text { Temperament } \\
\text { (mizaj) }\end{array}$ & Properties and functions & Application in uterine diseases \\
\hline 1 & Pimpinella anisum & Anison & Hot and dry & $\begin{array}{l}\text { Attenuant, wind dissolvent, } \\
\text { cleaner, Increase the flow of } \\
\text { urine, milk, and menstrual blood }\end{array}$ & $\begin{array}{l}\text { The decoction of this plant interrupts } \\
\text { the bleeding of the uterus. }\end{array}$ \\
\hline 2 & Foeniculum vulgare & Raziyanaj & Hot and dry & $\begin{array}{l}\text { Thick wind dissolvent, Increase } \\
\text { the flow of urine and menstrual } \\
\text { blood }\end{array}$ & \\
\hline 3 & Carum cupticum & Nankhah & Hot and dry & $\begin{array}{l}\text { Wind dissolvent, Increase } \\
\text { the flow of urine, milk, and } \\
\text { menstrual blood }\end{array}$ & $\begin{array}{l}\text { Vaginal suppository and vaginal enema } \\
\text { (Forzajeh and Hoghneh) is used to } \\
\text { clean the uterus from moisturs and } \\
\text { dry it. }\end{array}$ \\
\hline 4 & Carum petroselinum & Fotrasalion & Hot and dry & $\begin{array}{l}\text { Wind and bloat dissolvent, } \\
\text { Increase the flow of urine and } \\
\text { menstrual blood }\end{array}$ & Forzajeh is useful in abortion \\
\hline 5 & Apium graveolens & Karafs & Hot and dry & $\begin{array}{l}\text { Blockage opener, Dissolvent, } \\
\text { Increase the flow of urine and } \\
\text { menstrual blood }\end{array}$ & \\
\hline 6 & Legoecia cuminoides & Ghordemana & Hot and dry & Dissolvent for thick bloating & \\
\hline 7 & Ruta graveolense & Sodab & Hot and dry & $\begin{array}{l}\text { Wind and bloat dissolvent, } \\
\text { Increase the flow of urine and } \\
\text { menstrual blood }\end{array}$ & $\begin{array}{l}\text { Forzajeh and Humol is useful in } \\
\text { abortion and improve the flow of } \\
\text { menstrual blood. }\end{array}$ \\
\hline \multirow[t]{2}{*}{8} & Anethum graveolens & Shebet & Hot and dry & $\begin{array}{l}\text { Dissolvent, Cocative, Blockage } \\
\text { opener and Increase the flow of } \\
\text { urine and menstrual blood }\end{array}$ & $\begin{array}{l}\text { Sitting in the decoction of leaves and } \\
\text { seeds is useful for the diseases of the } \\
\text { uterus. }\end{array}$ \\
\hline & & & & & $\begin{array}{l}\text { Drinking decoction of its leaves and } \\
\text { fresh or dry seeds is beneficial to } \\
\text { remove and breaking down the wind. }\end{array}$ \\
\hline \multirow[t]{3}{*}{9} & Opopanax chironium & Javshir & Hot and dry & $\begin{array}{l}\text { Wind dissolvent, Blockage } \\
\text { opener and eliminate uterus } \\
\text { bloat }\end{array}$ & $\begin{array}{l}\text { The decoction is useful to improve the } \\
\text { flow of urine and menstrual blood and } \\
\text { modifying the uterus and breaking } \\
\text { down its rigidity. }\end{array}$ \\
\hline & & & & & $\begin{array}{l}\text { Its Humol is extremely powerful } \\
\text { in improve the flow of menstrual } \\
\text { bleeding. }\end{array}$ \\
\hline & & & & & $\begin{array}{l}\text { Orally or vaginally, it breaks down } \\
\text { winds in the uterus and eliminates the } \\
\text { stiffness of the uterus. }\end{array}$ \\
\hline 10 & Origanum majorana & Marzanjosh & Hot and dry & $\begin{array}{l}\text { Attenuant, dissolvent, Blockage } \\
\text { opener, Cleaner, Absorbent }\end{array}$ & $\begin{array}{l}\text { Rubbing it on the limbs causes } \\
\text { disintegration of phlegmatic swelling. }\end{array}$ \\
\hline & & & & & $\begin{array}{l}\text { Its Forzajeh is a modulator of the flow } \\
\text { of menstrual bleeding. }\end{array}$ \\
\hline 11 & $\begin{array}{l}\text { Matricaria } \\
\text { chamomilla }\end{array}$ & Babonaj & Hot and dry & $\begin{array}{l}\text { Attenuant, Dissolvent, Blockage } \\
\text { opener, Increase the flow of } \\
\text { urine, milk and menstrual blood, }\end{array}$ & $\begin{array}{l}\text { Oral and topical is beneficial. } \\
\text { In many diseases of the uterus, sitting }\end{array}$ \\
\hline & & & & $\begin{array}{l}\text { Relaxation of fatigue and pain in } \\
\text { the uterus and breaking down } \\
\text { the accumulated winds in the } \\
\text { limbs. }\end{array}$ & place is useful. \\
\hline \multirow[t]{3}{*}{12} & Artemisia vulgaris & Berenjasf & Hot and dry & $\begin{array}{l}\text { Attenuant, Blockage opener, } \\
\text { Increase the flow of urine }\end{array}$ & $\begin{array}{l}\text { Sitting in the decoction to relieve } \\
\text { menstrual blood and urine retention, } \\
\text { difficult delivery, cervical closure and } \\
\text { swelling are beneficial. }\end{array}$ \\
\hline & & & & & $\begin{array}{l}\text { Pouring the decoction of this plant and } \\
\text { rubbing it on the abdomen can help } \\
\text { relieve urinary and menstrual blood } \\
\text { retention, swelling and pain relief. }\end{array}$ \\
\hline & & & & & $\begin{array}{l}\text { Humol of its extract with myrrh is } \\
\text { useful for disposal of waste materials } \\
\text { from the uterus. }\end{array}$ \\
\hline
\end{tabular}




\begin{tabular}{|c|c|c|c|c|c|}
\hline & Scientific name & Traditional name & $\begin{array}{l}\text { Temperament } \\
\text { (mizaj) }\end{array}$ & Properties and functions & Application in uterine diseases \\
\hline \multirow[t]{2}{*}{13} & \multirow[t]{2}{*}{$\begin{array}{l}\text { Artemisia } \\
\text { absinthium }\end{array}$} & \multirow[t]{2}{*}{ Afsantin } & \multirow[t]{2}{*}{ Hot and dry } & $\begin{array}{l}\text { Blockage opener, Attenuant, } \\
\text { astringent, }\end{array}$ & $\begin{array}{l}\text { Its Forzajeh with honey is beneficial to } \\
\text { menstrual bleeding. }\end{array}$ \\
\hline & & & & $\begin{array}{l}\text { Laxative for bile and other bitter } \\
\text { humors }\end{array}$ & $\begin{array}{l}\text { Facilitate the exit of urine, menstrual } \\
\text { blood, milk and sweat. }\end{array}$ \\
\hline 14 & Thymus serpyllum & Namam & Hot and dry & Blockage opener, Strengthening & $\begin{array}{l}\text { It facilitates the removal of urine and } \\
\text { menstrual bleeding and relieves the } \\
\text { infection. }\end{array}$ \\
\hline 15 & Artemisia herba-alba & Shih & Hot and dry & $\begin{array}{l}\text { Blockage opener, phlegm } \\
\text { deferent, wind Dissolvent, } \\
\text { laxative for infectious humors }\end{array}$ & \\
\hline \multirow[t]{2}{*}{16} & \multirow[t]{2}{*}{ Carum carvi } & \multirow[t]{2}{*}{ cummon } & \multirow[t]{2}{*}{ Hot and dry } & \multirow[t]{2}{*}{$\begin{array}{l}\text { Attenuant, deferent, Dissolvent, } \\
\text { Astringent }\end{array}$} & $\begin{array}{l}\text { Orally used to breakdown the wind } \\
\text { and bloat and facilitate urine and } \\
\text { menstrual blood output. }\end{array}$ \\
\hline & & & & & $\begin{array}{l}\text { Enema (Hoghneh) with other } \\
\text { herbal medicine decoction leads to } \\
\text { depletion of wind and bloat. }\end{array}$ \\
\hline 17 & Peganum harmala & Harmal & Hot and dry & $\begin{array}{l}\text { Cleaner, Dissolvent for intestinal } \\
\text { bloating and thick material, } \\
\text { Increase the flow of urine, milk } \\
\text { and menstrual blood, laxative for } \\
\text { melancholy and thick phlegm }\end{array}$ & $\begin{array}{l}\text { Its enema (Hoghneh) is useful in } \\
\text { kidney and uterus coldness }\end{array}$ \\
\hline 18 & Valeriana celtica & Nardin & Hot and dry & $\begin{array}{l}\text { Increase the flow of urine and } \\
\text { menstrual blood }\end{array}$ & $\begin{array}{l}\text { Sitting in its decoction is beneficial in } \\
\text { uterus diseases }\end{array}$ \\
\hline 19 & Jasminum officinalis & Yasamin & Hot and dry & $\begin{array}{l}\text { Blockage opener, Increase the } \\
\text { flow of urine and menstrual } \\
\text { blood }\end{array}$ & $\begin{array}{l}\text { Cathartic for melancholy, bile and } \\
\text { phlegm and it eliminates thick wind. }\end{array}$ \\
\hline \multirow[t]{2}{*}{20} & \multirow[t]{2}{*}{ Costus sp. } & \multirow[t]{2}{*}{ Ghost } & \multirow[t]{2}{*}{ Hot and dry } & \multirow[t]{2}{*}{$\begin{array}{l}\text { Facilitates menstrual blood and } \\
\text { urine output. }\end{array}$} & $\begin{array}{l}\text { Eating it with honey is used to absorb } \\
\text { moisture and phlegm and removing } \\
\text { them. }\end{array}$ \\
\hline & & & & & $\begin{array}{l}\text { Vaginal suppositories and sitting in } \\
\text { the decoction of this herb is beneficial } \\
\text { for menstrual bleeding and relief of } \\
\text { uterine pains. }\end{array}$ \\
\hline 21 & Melilotus officinalis & Eklil al-malek & Hot and dry & Dissolvent, cocative, astringent & $\begin{array}{l}\text { Drinking decoction of the leaves and } \\
\text { branches is useful for Facilitate the } \\
\text { menstrual blood and urination. }\end{array}$ \\
\hline 22 & $\begin{array}{l}\text { Citrus medica var. } \\
\text { cedrata }\end{array}$ & Otroj & Hot and dry & Blockage opener & \\
\hline \multirow[t]{2}{*}{23} & \multirow[t]{2}{*}{ Ficus carica } & \multirow[t]{2}{*}{ Tin } & \multirow[t]{2}{*}{ Hot and wet } & \multirow[t]{2}{*}{$\begin{array}{l}\text { Dissolvent, Attenuant, Strong } \\
\text { cleaner and mild laxative. }\end{array}$} & $\begin{array}{l}\text { Vaginal suppository (Humol) with } \\
\text { honey in wool fabric is used to clean } \\
\text { up uterus wounds, absorb infectious } \\
\text { moisture and discontinue uterine } \\
\text { bleeding. }\end{array}$ \\
\hline & & & & & Removes the rigidity of the uterine. \\
\hline \multirow[t]{2}{*}{24} & \multirow[t]{2}{*}{ Althea officinalis } & \multirow[t]{2}{*}{ Khatmi } & \multirow[t]{2}{*}{ cold and dry } & \multirow[t]{2}{*}{$\begin{array}{l}\text { Dissolvent, Coactive, Relaxant } \\
\text { and laxative }\end{array}$} & $\begin{array}{l}\text { Sitting in the decoction is useful for } \\
\text { anal swellings and cervical adhesion. }\end{array}$ \\
\hline & & & & & $\begin{array}{l}\text { With duck fat and gum (samgh } \\
\text { al-botom), are experienced in } \\
\text { the uterus swellings and cervical } \\
\text { adhesion. }\end{array}$ \\
\hline \multirow[t]{2}{*}{25} & \multirow[t]{2}{*}{ Commiphora mukul } & \multirow[t]{2}{*}{ Mukul } & \multirow[t]{2}{*}{ Hot and dry } & \multirow{2}{*}{$\begin{array}{l}\text { Attenuante, Cleaner, laxative, } \\
\text { Blockage opener Facilitates the } \\
\text { exit of urine, menstrual blood, } \\
\text { and milk. }\end{array}$} & $\begin{array}{l}\text { It is useful in Difficult delivery and } \\
\text { menstrual retention. }\end{array}$ \\
\hline & & & & & $\begin{array}{l}\text { Vaginal suppository (Humol) is useful } \\
\text { for absorbing moistures from the } \\
\text { uterus and drying them, removing the } \\
\text { cervical adhesion and lowering the } \\
\text { fetus and Abortion. }\end{array}$ \\
\hline
\end{tabular}




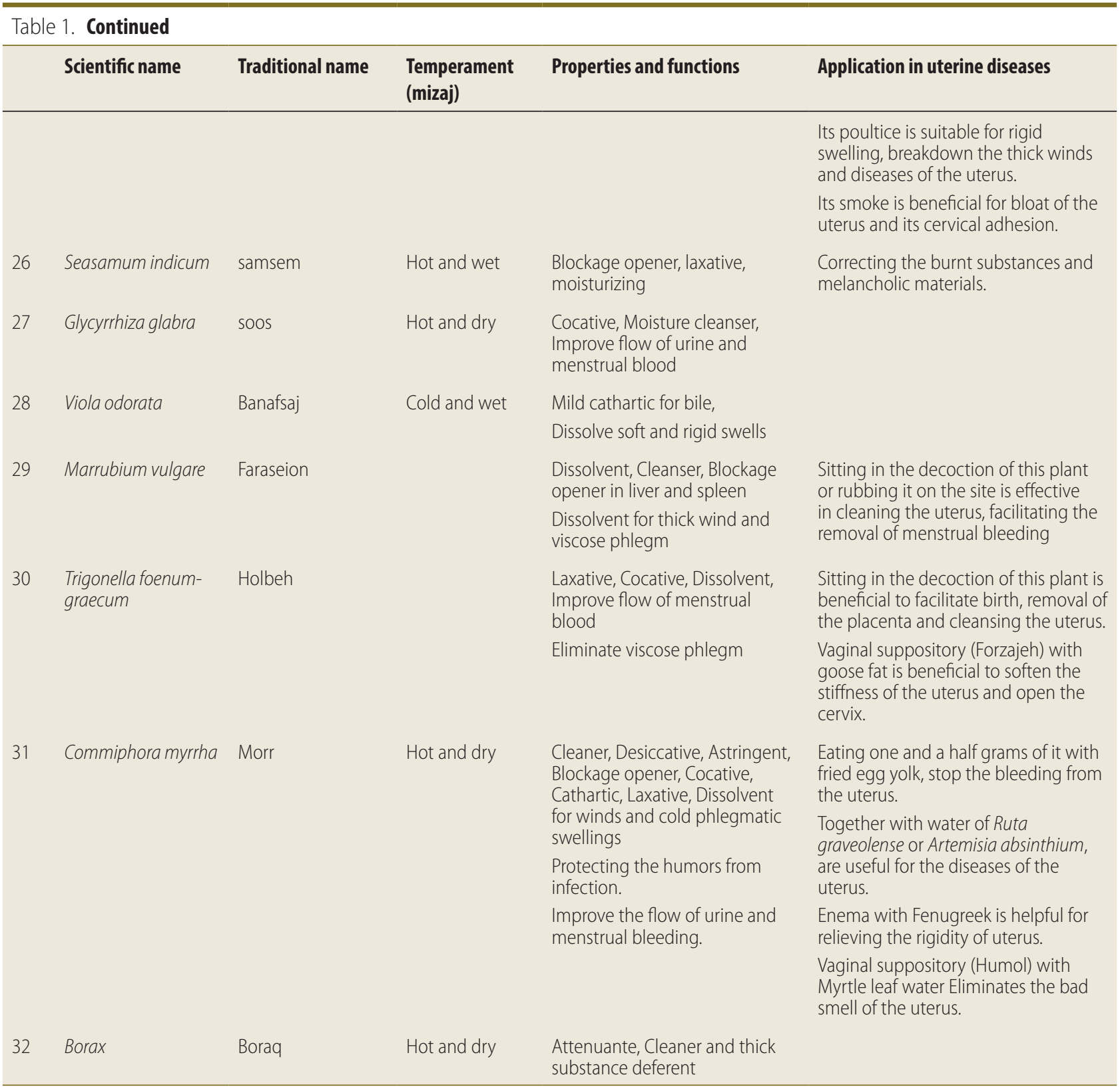

\begin{tabular}{|c|c|c|}
\hline $\begin{array}{l}\text { Dosage } \\
\text { form }\end{array}$ & $\begin{array}{l}\text { Scientific name of } \\
\text { ingredient }\end{array}$ & Preparation method \\
\hline Oral & $\begin{array}{l}\text { Pimpinella anisum } \\
\text { Apium graveolens } \\
\text { Foeniculum vulgare } \\
\text { Carum cupticum } \\
\text { Ruta graveolense } \\
\text { Carum petroselinum } \\
\text { Legoecia cuminoides }\end{array}$ & $\begin{array}{l}\text { All spices are boiled in water. } \\
\text { Then mix it with jasmine oil and } \\
\text { nervine oil and costus oil and } \\
\text { enter it in the uterus. }\end{array}$ \\
\hline
\end{tabular}

Table 3. Formulation of a topical medicine used in the
treatment of uterine bloating from kamel al-sina'ah. .11,24 $^{10}$

\begin{tabular}{lll}
\hline Dosage form & $\begin{array}{l}\text { Scientific name of } \\
\text { ingredient }\end{array}$ & Preparation method \\
\hline Topical & $\begin{array}{l}\text { Ruta graveolense } \\
\text { Anethum graveolens }\end{array}$ & $\begin{array}{l}\text { A mixture of both oil } \\
\text { is rubbed below the } \\
\text { umbilicus and above the } \\
\text { pubic. }\end{array}$
\end{tabular}




\begin{tabular}{|c|c|c|}
\hline Dosage form & $\begin{array}{l}\text { Scientific name of } \\
\text { ingredient }\end{array}$ & Preparation method \\
\hline $\begin{array}{l}\text { vaglnal Eneme } \\
\text { (hoghneh) }\end{array}$ & $\begin{array}{l}\text { Matricaria chamomilla } \\
\text { Anethum graveolens } \\
\text { Origanum majorana } \\
\text { Artemisia vulgaris } \\
\text { Artemisia absinthium } \\
\text { Thymus serpyllum } \\
\text { Artemisia herba-alba } \\
\text { Ruta graveolense } \\
\text { Apium graveolens } \\
\text { Foeniculum vulgare } \\
\text { Pimpinella anisum } \\
\text { Carum carvi } \\
\text { Carum cupticum } \\
\text { Peganum harmala } \\
\text { Valeriana celtica } \\
\text { Jasminum officinalis } \\
\text { Costus sp. }\end{array}$ & $\begin{array}{l}\text { All spices are boiled in } \\
\text { water. Then mix it with } \\
\text { jasmine oil and nardine } \\
\text { oil and costus oil and } \\
\text { enter it in the uterus. }\end{array}$ \\
\hline
\end{tabular}

Table 5. A formula of combination medicine of vaginal suppository (forzajeh) used in the treatment of uterine bloating from kamel al-sina'ah. ${ }^{11,24}$

\begin{tabular}{|c|c|c|}
\hline Dosage form & $\begin{array}{l}\text { Scientific name of } \\
\text { ingredient }\end{array}$ & Preparation method \\
\hline $\begin{array}{l}\text { Vaginal } \\
\text { suppository } \\
\text { (forzajeh) }\end{array}$ & $\begin{array}{l}\text { Ficus carica } \\
\text { Commiphora mukul } \\
\text { Carum carvi } \\
\text { Borax } \\
\text { Milk }\end{array}$ & $\begin{array}{l}\text { Dried figs are well peeled } \\
\text { and mixed with milk. Then } \\
\text { combine borax and mukul } \\
\text { and cumin with it and prepare } \\
\text { Forzajeh. }\end{array}$ \\
\hline
\end{tabular}

for $10 \mathrm{~s}$. The contraction and release of the muscles should be done 10 times and repeated 3 times a day. ${ }^{25,26}$ This exercise can be performed in any state (sitting, sleeping, working, etc.). It should be noted that exercising in the abdomen or back after having performed this exercise indicates that exercise has not been properly performed. During the contraction of pelvic floor muscles, other muscles, such as the abdomen, back, and hips, should be relaxed. ${ }^{26}$

There was no study on the effects of this exercise on the prevention of vaginal flatus. However, a study on the effect of pelvic floor muscle exercise on urinary incontinence has shown that 3 months of exercise in 36 patients resulted in 56\% improvement in patients, but did not effect on patients with moderate to severe incontinence. ${ }^{27}$

\section{Discussion}

In most Iranian traditional manuscripts, including the kamel al-Sina'ah, the canon of medicine, kholaseh al-Hekmah, Akbari medicine, etc. the uterus flatulence is an independent disease and its causes, complications, and treatments are detailed. However, in modern medicine, they have diagnosed this disease in a lesser amount and do not consider it as a disease. On the other hand, due to the lack of reporting by patients, the exact incidence and complications of this disease have not been determined.

Treatment of uterus flatulence in ITM includes series of measures such as improving nutrition, avoiding cold and flatulent foods, doing exercise, and appropriate sleep. In addition to these measures, the principles of treating the disease in traditional medicine include cleansing the body, strengthening the uterus, and adjusting the temperament of the uterus. First, the patient's body should be cleaned of substances causing the disease. Cleansing the body and the uterus is done with using appropriate laxatives. One of the most famous laxatives is Iyarej Fiqera, that is also introduced in the Avicenna book (the Canon of medicine) for cleaning the body in the uterus flatulence. In order to strengthen and modify the temperament of the uterus, various types of vaginal suppository (Forzajeh and Humol), and other appropriate dosage forms are used. Examples of these medicines are presented in Tables 4 and 5. In order to achieve treatment, the patient should observe all these remedies, failure to complete these treatments do not result in complete treatment, and the disease will not be eradicated, and will return again.

One of the cases that is very effective in the treatment of this condition and is partly taken into account in modern medicine is exercise. Exercise causes the body to warm and elevate intrinsic heat, and this heat can help to reduce winds in uterine. In traditional medicine, it is recommended that exercise is carried out in a general way throughout the body so that the heat produced is uniformly dispersed in the body. While in modern medicine, exercises designed to reduce vaginal flatus are localized and only related to the pelvic and perineal muscles, and do not involve the rest of the body. On the other hand, in modern medicine, uterus flatulence is less common and no complete studies have been done on it, there is no clear strategy for treating this disease.

Given the relatively complete recognition of ITM practitioners about this disease, a full description of this disease is available in most ITM books. Ibn Abbas in kamel al-Sina'ah said that the uterus bloating is the result of overcoming cold su'mizaj in the uterus, which causes reducing heat of the womb and ultimately leads to the creation of wind in the womb. Avicenna also considered the uterus flatulence as a result of overcoming coldness in the uterus and cervix. This coldness causes the closure of the cervix and retention winds in the uterus. This wind does not reside and penetrates into the tissue of the womb. Aqili in the kholaseh al-Hekmah book said, the dominance of cold su'mizaj over uterus and the production of winds due to heat weakness is one of the causes of infertility. Hakim Arzani in Akbari's medicine book introduces the uterus flatulence as a result of weakness in the uterus due to overcoming cold su'mizaj. Cold su'mizaj is one of the main causes of infertility in women. , $3,3,12^{2}$

As a result of this cold, su'mizaj and winds production in the uterus, pain, and stiffness are felt in the pubes area, the abdomen is stiff and pain is felt in the groin and even in the stomach. The area between the umbilicus and the pubes swells, so that when it's hit with the finger it gives out drum sound. Treatment of the disease is initially a cleansing of the body using laxatives, including Iyarajat. In the next step, warming up the uterus and breaking down the wind in the uterus using 
a variety of jovaresh and syrups. In preparing these medicines, the herbs with warming and cleansing characteristics are used, such as chamomile, dill, and marjoram. ${ }^{12}$

\section{Conclusion}

It is important to note that uterine flatulence is an indication of the cold su'mizaj of the uterus, which is the source of many of the problems in women, including infertility. Therefore, further studies are needed on this disease and its causes, as well as its relation with infertility, and the treatments provided in ITM is also should be considered.

\section{Conflict of Interest}

The authors declare that there is no known conflict of interest regarding this publication.

\section{Acknowledgment}

This study was supported by Ahvaz Jundishapour University of Medical Science in Iran.

\section{References}

1. Danforth DN. Danforth's obstetrics and gynecology: Lippincott Williams \& Wilkins; 2008.

2. Shah arzani M. Akbari medicine (tib-e-akbari). Qom: Resuscitation Institute of Natural Medicine, Jalal al-Din Publications; 2008.

3. MH Ak. Kholasat al hekmat. Qum: Esmaeilian Publication; 2006.

4. NJM NKC. Eksire Azam. Tehran: Iran University of Medical Sciences, Institute of History of Medicine, Islamic Medicine and Supplement; 2008.

5. Rayner J-A, Willis K, Burgess R. Women's use of complementary and alternative medicine for fertility enhancement: A review of the literature. J Altern Complement Med. 2011;17(8):685-90.

6. Coulson C, Jenkins J. Complementary and alternative medicine utilisation in NHS and private clinic settings: a United Kingdom survey of 400 infertility patients. J Exp Clin Assist Reprod. 2005;2(1):5.

7. Xue CC, Zhang AL, Lin V, Da Costa C, Story DF. Complementary and alternative medicine use in Australia: a national population-based survey J Altern Complement Med. 2007;13(6):643-50.
8. Jorjani I. Zakhire Kharazmshahi. Qum: Natural Resuscitation Institute; 2012.

9. (Avicenna) SA. Canon of medicine (Al Qanun Fil Tibb). Beirut, Lebanon: Arab Heritage Revival House; 2005.

10. NA S. Sharh al-asbab va al-alamat. Qum: Natural Resuscitation Institute; 2008.

11. AIA MA. Kamel al sanaat al tebbiyat (The Perfect Book of the Art of Medicine). Qum: Natural Resuscitation Institute jalalaldin; 2007.

12. AIA MA. Kamel al sanaat al tebbiyat (The Perfect Book of the Art of Medicine). qum: Natural Resuscitation Institute jalalaldin; 2007.

13. Tansaz M, Adhami S, Mokaberinejad R, Namavar Jahromi B, Atarzadeh F, Jaladat AM. An overview of the causes and symptoms of male infertility from the perspective of traditional persian medicine. Iran J Obstet Gyneco Infertil. 2016;18(182):11-7.

14. SL E. Medicine During the the Safavieh. Tehran: Tehran University; 1978.

15. S B. Infertility and contraception in Iran medicine. Tehran: Ismaeelian; 2010.

16. Allahdin S. Flatus vaginalis a distressing symptom. Int J Colorect Dis. 2011;26(11):1493-.

17. Krissi H, Medina C, Stanton SL. Vaginal wind-a new pelvic symptom. Int Urogynecol J. 2003;14(6):399-402

18. Kjølhede P, Wahlström J, Wingren G. Pelvic floor dysfunction after Burch colposuspension-a comprehensive study. Part I. Acta Obstet Gynecol Scand. 2005:84(9):894-901.

19. Buurman MBR, Lagro-Janssen ALM. Women's perception of postpartum pelvic floor dysfunction and their help-seeking behaviour: a qualitative interview study. Scand J Car Sci. 2013;27(2):406-13.

20. Nakagoe T, Sawai T, Tuji T, Nanashima A, Yamaguchi H, Yasutake T, et al. Successful transvaginal repair of a rectovaginal fistula developing after double-stapled anastomosis in low anterior resection: report of four cases. Surg Today. 1999;29(5):443-5.

21. Schloericke E, Hoffmann M, Zimmermann M, Kraus M, Bouchard R, Roblick UJ, et al. Transperineal omentum flap for the anatomic reconstruction of the rectovaginal space in the therapy of rectovaginal fistulas. Colorect Dis. 2012;14(5):604-10.

22. (Avicenna) SA. Translation and Description of avicenna's Healthcare Management. Tehran: Iran University of Medical Sciences; 2008

23. S A. Iranian Traditional Pharmacy and pharmaceutical dosage forms. Tehran: Chogan Publication; 2013

24. MH Ak. Makhzan ol Advieh (The Storehouse Medicaments). Tehran: Tehran University of Medical Sciences; 2008.

25. Cammu H, Van Nylen M, Amy J. A 10-year follow-up after Kegel pelvic floor muscle exercises for genuine stress incontinence. BJU Int. 2000;85(6):655-8.

26. Kegel AH. Progressive resistance exercise in the functional restoration of the perineal muscles. Am J Obstet Gynecol. 1948;56(2):238-48.

27. Elia G, Bergman A. Pelvic muscle exercises: when do they work? Obstet Gynecol. 1993;81(2):283-6.

This work is licensed under a Creative Commons Attribution-NonCommercial 3.0 Unported License which allows users to read, copy, distribute and make derivative works for non-commercial purposes from the material, as long as the author of the original work is cited properly. 